\title{
NEUTRALIZATION OF WASTE FILTER DUST WITH $\mathrm{CO}_{2}$
} NEVTRALIZACIJA ODPADNEGA FILTRSKEGA PRAHU $\mathrm{S} \mathrm{CO}_{2}$

\author{
Ana Kračun ${ }^{1,2}$, Ivan Anžel ${ }^{1}$, Lidija Fras Zemljič ${ }^{1}$, Andrej Stergaršek ${ }^{3}$ \\ ${ }^{1}$ University of Maribor, Faculty of Mechanical Engineering, Smetanova 17, 2000 Maribor, Slovenia \\ ${ }^{2}$ Institute of Metals and Technology, Lepi pot 11, 1000 Ljubljana, Slovenia \\ ${ }^{3}$ Kemek, d. o. o., Cimpermanova ulica 3, 1000 Ljubljana, Slovenia \\ ana.kracun@imt.si \\ Prejem rokopisa - received: 2014-09-29; sprejem za objavo - accepted for publication: 2014-12-12
}

\author{
doi: $10.17222 / \mathrm{mit} .2014 .247$
}

\begin{abstract}
In this paper we report on the possibility of neutralizing filter dust from Talum Livarna d.o.o. The filter dust that remains after cleaning flue gas with the classification number of waste $101009 *$ is alkaline and contains heavy metals, non-metals, organic pollutants, and, therefore, has the properties of hazardous waste. The possibility of neutralizing this dust with $\mathrm{CO}_{2}$ was studied. The results showed that the treatment successfully lowered the $\mathrm{pH}$ value between the limits 6 and 9 , which is within the legal constraints of pollution for strong acidic or alkaline waste. The contents of the hazardous substances were lowered, i.e., As, Cu, $\mathrm{Ba}, \mathrm{Zn}, \mathrm{Cd}, \mathrm{Cr}, \mathrm{Ni}, \mathrm{Pb}, \mathrm{Sn}, \mathrm{Mn}$ and $\mathrm{V}$, with percolation values that are below the level of the prescribed threshold-limit values for substances that allows their disposal in non-hazardous waste landfills. Only the percolation values of $\mathrm{Sb}, \mathrm{Cd}, \mathrm{Mo}$ and $\mathrm{Se}$ exceed the prescribed threshold limit values of substances that allow their disposal in inert waste landfills. The XRD analysis after the neutralization of the filter dust using $\mathrm{CO}_{2}$ showed no presence of $\mathrm{CaO}$. The neutralized filter dust can be land filled as a stabilized and unreactive waste in landfills for nonhazardous wastes. Their properties also offer the possibility for incorporating them into some other material or product, such as the production of new composite materials, their use in construction products and perhaps cements or usage in backfills.
\end{abstract}

Keywords: hazardous waste, filter dust, neutralization, stabilization, chemical properties

Raziskali smo možnost nevtralizacije filtrskega prahu iz podjetja Talum Livarna, d. o. o. Filtrski prah po čiščenju dimnih plinov s klasifikacijsko številko odpadka $101009^{*}$ je alkalen, vsebuje težke kovine, nekovine, organska onesnaževala, zato ima lastnosti nevarnega odpadka. Filtrski prah smo nevtralizirali s $\mathrm{CO}_{2}$, da je nastal pretežno amorfen produkt. Po obdelavi smo uspešno znižali pH-vrednost v meje med 6 in 9, kar je v dovoljenem območju za odpadke, onesnažene z močno kislino ali bazo. Prav tako je bila zmanjšana vsebnost nevarnih snovi, in sicer $\mathrm{As}, \mathrm{Cu}, \mathrm{Ba}, \mathrm{Zn}, \mathrm{Cd}, \mathrm{Cr}, \mathrm{Ni}, \mathrm{Pb}, \mathrm{Sn}, \mathrm{Mn}$ in $\mathrm{V}$, tako da so izluževalne vrednosti pod mejo predpisanih parametrov izlužka in je tako dovoljeno odlaganje na odlagališčih za nenevarne odpadke. Samo izluževalne vrednosti $\mathrm{Sb}, \mathrm{Cd}$, Mo in Se še prekoračujejo predpisane mejne vrednosti, ki so dovoljene za odlaganje na odlagališčih za inertne odpadke. XRD-analiza po nevtralizaciji filtrskega prahu $\mathrm{s}^{\mathrm{CO}_{2}}$ ni pokazala prisotnosti CaO. Nevtraliziran filtrski prah se lahko odloži kot stabiliziran in nereaktiven odpadek na odlagališčih nenevarnih odpadkov. Glede na lastnosti obstaja možnost predelave in uporabe v koristne namene, npr. za proizvodnjo novih kompozitnih materialov, gradbenih izdelkov, morda cementa ali za zasipavanje.

Ključne besede: nevarni odpadki, filtrski prah, nevtralizacija, stabilizacija, kemijske lastnosti

\section{INTRODUCTION}

Hazardous wastes are a problem of modern civilization and therefore need to be handled in a prudent manner. A rapid increase in their amount, negative effects on the environment and a growing environmental awareness have led to changes in the field of waste management in recent decades. These factors have contributed to stricter regulations and the development of new technical and operational solutions. ${ }^{1,2}$ The strategy of waste management in Slovenia is directed towards actions that enable the overseeing, removal and reduction of the harmful effects of these wastes on the environment and humans, as well as their preparation for reuse, recycle and use as an energy source. ${ }^{2}$

The metallurgical industry is a major source of potentially hazardous waste materials, those by-products of the production of metals and alloys. These metallurgical wastes consist mainly of slags and dust sludges that result from flue-gas filtering. These so-called waste materials can be potentially utilized as resources, for example, dust from the EAF process can be used as a source of $\mathrm{Zn},{ }^{3,4}$ metallurgical slags can be used in the production of building materials. ${ }^{5} \mathrm{~A}$ special aspect of the steel industry that requires particular attention is the production of stainless steel. During stainless-steel production, chromium oxidation occurs, which leads to the formation of $\mathrm{CrO}_{x}$ phases. They not only represent a loss from the production point of view, ${ }^{6-8}$ but also represent an environmental risk, because they can oxidize to dangerous hexavalent chromium $\left(\mathrm{Cr}^{6+}\right) .{ }^{9}$ During the melting of secondary aluminium contaminated with oil, paint or plastic flue gases that contain dust contaminated with heavy metals, nonmetals, dioxins, furans and fluorides. ${ }^{10}$

Waste filter dust is formed inside the exhaust gas treatment apparatus of foundry furnaces during operation with help of an additive DESOMIX HK. The additive DESOMIX $\mathrm{HK}$ is a mixture of calcium hydroxide $\left[\mathrm{Ca}(\mathrm{OH})_{2}\right]$ and active chalk. Filter dust is classified as a hazardous waste with a classification number 1010 09*, which puts it as far as regulation is concerned ${ }^{1}$ amongst the group of dusts that contain dangerous substances. 
The filter dusts are homogenous, alkaline, contain heavy metals, nonmetals, dioxins, furans and fluorides. Because the limit values of these toxic substances are exceeded during leeching, it is determined that these dusts have the properties of hazardous waste. Therefore, it has to be deposited in accordance with the relevant regulations. ${ }^{2}$ Industrial wastes are deposited in subterranean depots, usually prepared in closed coal and ore mines. ${ }^{11}$

There are many waste substances that react with carbon dioxide, for example, metallurgic slags, dusts from industrial thermical processes, combustion remains in which calcium oxide is a key component. The reaction between calcium hydroxide $\left[\mathrm{Ca}(\mathrm{OH})_{2}\right]$ and carbon dioxide $\left(\mathrm{CO}_{2}\right)$ is called carbonization. It is a natural reaction between an oxide or a base and $\mathrm{CO}_{2} \cdot{ }^{12,13}$ Direct binding between $\mathrm{CO}_{2}$ and calcium hydroxide is slow. However, it can be accelerated with the addition of water. In such cases the $\mathrm{CO}_{2}$ dissolves in water and dissociates and reacts with the dissolved and dissociated calcium hydroxide, therefore forming carbonate materials. ${ }^{12,13}$ During the formation of these carbonate materials the $\mathrm{pH}$ of the waste dust decreases, which results in the minimal solubility of the metals present in the waste dust. ${ }^{12-14}$ Complete carbonization can decrease the leaching of metals by $80 \% .{ }^{14-16}$ Previous research ${ }^{14-28}$ has shown that metal stabilization processes are more efficient if the treatment of the waste dust is conducted over an extended period of time and at high $\mathrm{CO}_{2}$ concentrations.

The main goal of this research was to determine whether it is possible to obtain a chemically stable product from waste filter dust with the process of neutralization using $\mathrm{CO}_{2}$. This would also enable this material to be reused in some other useful application or at least to process it enough so that long-term monitored deposition would be possible according to Slovenian regulations. ${ }^{2}$ Should the treated waste powder leaching values be inside the legal constraints for nonhazardous waste there would be a possibility that this waste could be deposited as a cost-reducing measure in dumps for nonhazardous waste. If it could achieve the constraints for inert waste it could be reused for practical purposes, for example, the production of new composite materials, use in construction materials, perhaps in cements or use in landfills.

\section{EXPERIMENTAL}

Filter dust, a by-product of the treatment of exhaust gases, is classified as a hazardous waste with the classification number 1010 09*. The analyzed sample comes from the release of a exhaust-gas treatment apparatus filter L9 in the company Talum Livarna, d. o. o.

The granulometric composition of the filter dust and the average particle size was determined with a device for laser-diffraction particle size analysis Cilas 1064. A qualitative analysis of the sample microstructure was facilitated using a high-resolution Scanning Electron
Microscope SIRION NC 400, equipped with NICA brand EDS detector. The X-ray analysis was conducted using a Philips XRD-analyzer W1800 hardware and X'pert High Score software.

\subsection{Neutralization of the filter dust with $\mathrm{CO}_{2}$}

The first step in this research was the determination of the initial $\mathrm{pH}$ of the leachate of the filter dust sample originating from Talum Livarna, d. o. o. Three samples with different moisture contents were prepared:

- $11 \%$ moisture content (sample label NFP1).

- $8 \%$ moisture content (sample label NFP2)

- $14 \%$ moisture content (sample label NFP3).

The moisturized samples were stirred using a glass rod, which helped to achieve a uniform water consistency of the sample. A Rushton mixer and a supply tube for the $\mathrm{CO}_{2}$ were placed inside a glass beaker. The samples were exposed to a flow of $10 \mathrm{~L} / \mathrm{min}$ of $\mathrm{CO}_{2}$ for a period of $1 \mathrm{~h}$.

The leaching and neutralization of the waste filter dust were carried out in accordance with the standard SIST EN 12457 - 4 (24 h leaching with water; ratio water/solid was 10/1). This was followed by a measurement of the $\mathrm{pH}$ and the leached inorganic parameters (metals) with help of the ICP-MS method. The ICP-MS device ionizes the sample with an inductively coupled plasma of argon gas. The ionized particles of the sample are then directed into a mass spectrometer. With the help of the ICP the presence of the following elements could be determined: $\mathrm{Ag}, \mathrm{Al}, \mathrm{As}, \mathrm{Ba}, \mathrm{Ca}, \mathrm{Cd}, \mathrm{Co}, \mathrm{Cr}, \mathrm{Cu}, \mathrm{Fe}$, $\mathrm{Mn}, \mathrm{Ni}, \mathrm{Pb}, \mathrm{Sb}, \mathrm{Se}, \mathrm{Sn}, \mathrm{Sr}, \mathrm{Zn}, \mathrm{B}, \mathrm{Be}, \mathrm{Mo}, \mathrm{Tl}, \mathrm{V}$.

\section{RESULTS AND DISCUSSION}

\subsection{Analysis of waste filter dust}

With the aid of laser diffraction we determined that the sizes of the filter particles range from $0.47 \mu \mathrm{m}$ to $47.30 \mu \mathrm{m}$. Some $20 \%$ of the particles are in the size range between $0.47 \mu \mathrm{m}$ and $10 \mu \mathrm{m}$, while the remaining

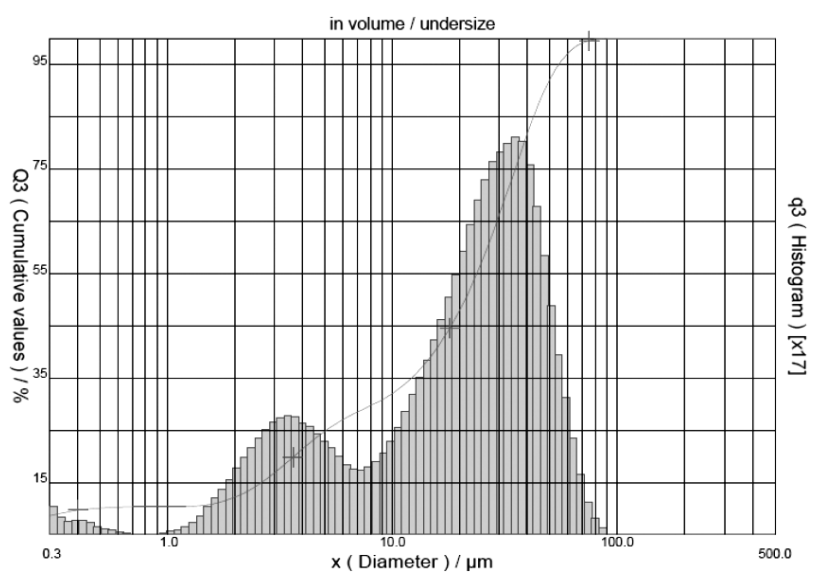

Figure 1: Size of the filter particulates

Slika 1: Velikost delcev filtrskega prahu 


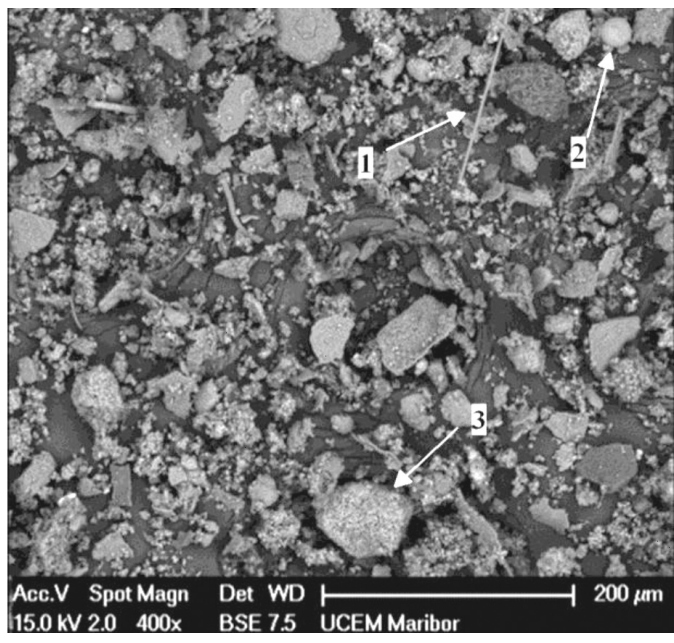

Figure 2: SEM analysis of filter dust: 1-rod-shaped particle, 2-spherical particle, 3-asymmetrical particle

Slika 2: SEM-analiza filtrskega prahu: 1-paličast delec, 2-sferičen delec, 3-asimetričen delec

$80 \%$ fall between $10 \mu \mathrm{m}$ and $47.30 \mu \mathrm{m}$. Figure 1 shows the size of filter particulates.

The SEM analysis of the sample dust showed that the morphology of the sample is not uniform. The particles were of different shapes, i.e., rod-shaped, spherical and asymmetrical (Figure 2). The particles also differed according to the chemical composition. The EDS analysis of the sample dust showed asymmetrical particles that had peaks for the elements: O, Al, Ca and $\mathrm{Zn}$. The rod-shaped particles had peaks for the elements: $\mathrm{O}, \mathrm{Na}$, $\mathrm{Mg}, \mathrm{Al}, \mathrm{Si}, \mathrm{K}$ and $\mathrm{Ca}$. The spherical shaped had peaks for the elements: O, Si, Ti, Mg, Zn, Al, Si, Ca in K. Recurring elements with in all shapes were elements: O, $\mathrm{Al}$ and $\mathrm{Ca}$.

The results of the chemical analysis of the waste filter dust are presented in Table $\mathbf{1 .}$

Table 1: Levels of measured parameters in the filter dust

Tabela 1: Vsebnost izmerjenih parametrov v filtrskem prahu

\begin{tabular}{|c|c|}
\hline Parameter & $\begin{array}{c}\text { Amount in the s. s. sample, } \\
\mathrm{mg} / \mathrm{kg}\end{array}$ \\
\hline $\mathrm{Al}$ & 2.1 \\
\hline $\mathrm{Sb}$ & 45.1 \\
\hline As & 10.0 \\
\hline $\mathrm{Cu}$ & 540.2 \\
\hline $\mathrm{Ba}$ & 3225.3 \\
\hline $\mathrm{Zn}$ & 2501.6 \\
\hline $\mathrm{Cd}$ & 24.7 \\
\hline $\mathrm{Cr}$ & 154.7 \\
\hline Mo & 15.4 \\
\hline $\mathrm{Ni}$ & 128.0 \\
\hline $\mathrm{Pb}$ & 282.3 \\
\hline $\mathrm{Se}$ & 20.2 \\
\hline $\mathrm{Co}$ & 2.1 \\
\hline $\mathrm{Sn}$ & 130.9 \\
\hline $\mathrm{Mn}$ & 130.3 \\
\hline $\mathrm{Tl}$ & 0.6 \\
\hline V & 15.4 \\
\hline
\end{tabular}

The chemical analysis also revealed that the samples contained $3.5 \%$ of moisture.

\subsection{Filter-dust leachate analysis}

The filter dust leachate contains high levels of heavy metals, such as: $\mathrm{Sb}, \mathrm{Cu}, \mathrm{Ba}, \mathrm{Cd}, \mathrm{Mo}, \mathrm{Ni}$, Se. It contains chlorides and fluorides. Present are also As, $\mathrm{Zn}, \mathrm{Cr}, \mathrm{Pb}$, $\mathrm{Co}, \mathrm{Sn}, \mathrm{Mn}, \mathrm{Tl}$ and $\mathrm{V}$ (Table 2). In the presence of water these chemical elements could leach into the soil and damage the environment, if the waste dust were to be deposited freely. It can be seen by observing Table 2 that some quantities of leached heavy metals exceed the limiting values for dumping on sites equipped to handle inert waste. The leachate of filter dust has a highly alkaline $\mathrm{pH}$ value of 12.71 . The data shows that the waste filter dust is of a heterogeneous composition and that it presents a hazard to the environment and it could have a great impact on the chemical and ecological balance, if not deposited correctly.

\subsection{Analysis of filter-dust leachate neutralized with $\mathrm{CO}_{2}$}

The aim of the neutralization experiment with $\mathrm{CO}_{2}$ was to evaluate the reduction of the $\mathrm{pH}$ values and the inorganic parameters and to attain, if it is possible, a chemically stable product that could be safely and harmlessly stored or deposited. The results show that the $\mathrm{pH}$ values could be reduced with this process, as shown in Figure 3.

The leachate $\mathrm{pH}$ values for the samples NFP1, NFP2 and NFP3 were monitored for a period of $32 \mathrm{~d}$. The chemical stability of the neutralized samples was satisfactory and the $\mathrm{pH}$ values were between 6 and 9. The attained $\mathrm{pH}$ values confirm that the waste is not contaminated with a strong acid or base. Because of the leachate exposure to $\mathrm{CO}_{2}$ found in the surrounding air, metal

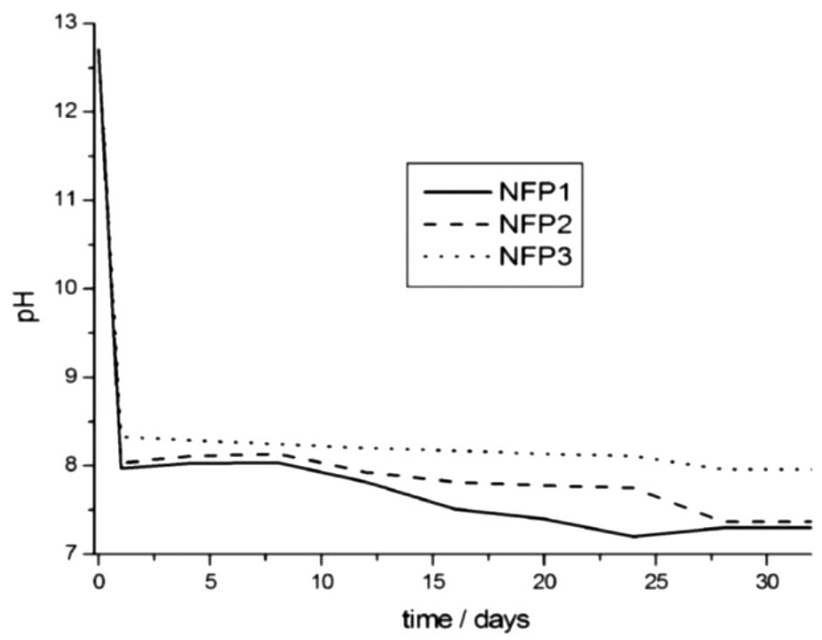

Figure 3: Filter dust leachate $\mathrm{pH}$ values of samples NFP1, NFP2, NFP3

Slika 3: pH-vrednosti izlužkov vzorcev NFP1, NFP2 in NFP3 
Table 2: Leachate results for chosen parameters in the samples NFP1, NFP2, NFP3 and filter dust - compared to limiting legal constraints Tabela 2: Vrednosti izluževanja nevarnih snovi vzorca NFP1, NFP2, NFP3 in filtrskega prahu - primerjava z zakonodajnimi vrednostmi

\begin{tabular}{|c|c|c|c|c|c|c|c|}
\hline \multirow{2}{*}{ Parameter } & \multirow{2}{*}{$\begin{array}{l}\text { Filter dust } \\
\text { leachate } \\
\text { result mg/kg }\end{array}$} & \multirow{2}{*}{$\begin{array}{c}\mathrm{CO}_{2} \mathrm{NFP1} \\
\text { neutralized filter } \\
\text { dust leachate } \\
\text { result } \mathrm{mg} / \mathrm{kg}\end{array}$} & \multirow{2}{*}{$\begin{array}{c}\mathrm{CO}_{2} \mathrm{NFP} 2 \\
\text { neutralized filter } \\
\text { dust leachate } \\
\text { result } \mathrm{mg} / \mathrm{kg}\end{array}$} & \multirow{2}{*}{$\begin{array}{c}\mathrm{CO}_{2} \mathrm{NFP} 3 \\
\text { neutralized filter } \\
\text { dust leachate } \\
\text { result } \mathrm{mg} / \mathrm{kg}\end{array}$} & \multicolumn{3}{|c|}{$\begin{array}{l}\text { Limiting legal constraint of a parameter } \\
\qquad L / S=10 \mathrm{~L} / \mathrm{kg}(\mathrm{mg} / \mathrm{kg})\end{array}$} \\
\hline & & & & & Inert waste & $\begin{array}{l}\text { Hazardous } \\
\text { waste }\end{array}$ & $\begin{array}{c}\text { Non-hazardous } \\
\text { waste }\end{array}$ \\
\hline $\mathrm{Sb}$ & 0.26 & 0.34 & 0.26 & 0.31 & 0.06 & 5 & 0.7 \\
\hline As & 0.01 & 0.01 & 0.01 & 0.01 & 0.5 & 25 & 2 \\
\hline $\mathrm{Cu}$ & 2.63 & 12.99 & 1.95 & 0.38 & 2 & 100 & 50 \\
\hline $\mathrm{Ba}$ & 73.17 & 5.19 & 4.71 & 4.86 & 20 & 300 & 100 \\
\hline $\mathrm{Zn}$ & 3.41 & 0.77 & 0.38 & 0.37 & 4 & 200 & 50 \\
\hline $\mathrm{Cd}$ & 0.18 & 0.21 & 0.11 & 0.11 & 0.04 & 5 & 1 \\
\hline $\mathrm{Cr}$ & 0.01 & 0 & 0 & 0 & 0.5 & 70 & 10 \\
\hline Mo & 0.49 & 0.77 & 0.73 & 0.65 & 0.5 & 30 & 10 \\
\hline $\mathrm{Ni}$ & 0.44 & 0.20 & 0.15 & 0.11 & 0.4 & 40 & 10 \\
\hline $\mathrm{Pb}$ & 0 & 0.05 & 0.01 & 0.04 & 0.5 & 50 & 10 \\
\hline $\mathrm{Se}$ & 0.19 & 0.36 & 0.28 & 0.28 & 0.1 & 7 & 0.5 \\
\hline $\mathrm{Co}$ & 0 & 0.01 & 0 & 0 & & & \\
\hline $\mathrm{Sn}$ & 0.05 & 0.01 & 0.01 & 0.01 & & & \\
\hline $\mathrm{Mn}$ & 3.73 & 1.92 & 1.57 & 1.51 & & & \\
\hline $\mathrm{Tl}$ & 0 & 0.04 & 0.03 & 0.02 & & & \\
\hline $\mathrm{V}$ & 1.00 & 0.31 & 0.23 & 0.10 & & & \\
\hline
\end{tabular}

oxides bound to $\mathrm{CO}_{2}$ and there was an additional drop in the $\mathrm{pH}$ over a period of $32 \mathrm{~d}$. In sample NFP1 the initial $\mathrm{pH}$ was 12.71 , while after neutralization it dropped to 7.97 , and after a period of 32 days it was measured at 7.30 .

Table 2 presents the leaching results for the chosen leachate parameters of the samples NFP1, NFP2, NFP3 and the waste filter dust, compared to environmental legal constraints. The neutralization reduced the leachate values of the $\mathrm{As}, \mathrm{Cu}, \mathrm{Ba}, \mathrm{Zn}, \mathrm{Cr}, \mathrm{Ni}, \mathrm{Pb}, \mathrm{Sn}, \mathrm{Mn}$ and $\mathrm{V}$ to a level that could enable this waste to be deposited as non-hazardous waste. The leachate values for the $\mathrm{Sb}, \mathrm{Cd}$, Mo and Se remained too high for this waste to be deposited as inert waste. The highest heavy-metal reduction occurred in sample NFP3 with $14 \%$ moisture. This proves that the reaction of the carbonization is the fastest and most successful when the moisture is high and there is a lot of water present. During the neutralization waste filter dust in samples NFP1, NFP2 and NFP3 $\mathrm{CO}_{2}$ underwent a chemical reaction and bound to calcium hydroxide $\left[\mathrm{Ca}(\mathrm{OH})_{2}\right]$ in the presence of moisture. The carbonate $\mathrm{CaCO}_{3}$ was formed. An XRD analysis showed no presence of $\mathrm{CaO}$ in any of the samples, which indicates that the carbonization was complete. The formed carbonates are less soluble and less alkaline than the oxides and hydroxides found in the filter dust.

\section{CONCLUSIONS}

Neutralization helped to transform a hazardous waste into a non-hazardous waste, which could be deposited on sites for non-hazardous waste. $\mathrm{CO}_{2}$ neutralization presents a viable technological solution for the stabilization of waste filter dust. The neutralized dust could be used as a bulk material.

\section{Acknowledgment}

The authors would like to thank dr. Marko Homšak and Talum Inštitut d.o.o. for their technical support.

\section{REFERENCES}

${ }^{1}$ Uredba o odlaganju odpadkov na odlagališčih, Uradni list RS, št. 61/2011, str. 8857, Available from World Wide Web: http://www. uradni-list.si/1/content?id=104808 [7. 4. 2014] (in Slovene)

${ }^{2}$ Uredba o odpadkih, Uradni list RS, št. 103/2011, str. 13935, Available from World Wide Web: http://www.uradni-list.si/1/ content?id=106484 [27. 4. 2014] (in Slovene)

${ }^{3}$ P. Drissen, A. Ehrenberg, M. Kuhn, D. Mudersbach, Recent Development in Slag Treatment and Dust Recycling, Steel Research International, 80 (2009) 10, 737-745, doi:10.2374/SRI09SP055

${ }^{4}$ C. Scharf, A. Ditze, Processing of Agglomerated Red Filter Dust in the Converter Operation from Metallurgical Point of View, Steel Research International, 84 (2013) 9, 917-925, doi:10.1002/srin. 201300126

${ }^{5}$ V. Zalar Serjun, B. Mirtič, A. Mladenovič, Evaluation of ladle slag as a potential material for building and civil engineering, Mater. Tehnol., 47 (2013) 5, 543-550

${ }^{6}$ B. Arh, F. Vode, F. Tehovnik, J. Burja, Reduction of chromium oxides with calcium carbide during the stainless steelmaking process, Metalurgija, 54 (2015) 2, 368-370

${ }^{7}$ J. Burja, F. Tehovnik, F. Vode, B. Arh, Microstructural characterization of chromium slags, Metalurgija, 54 (2015) 2, 379-382

${ }^{8}$ J. Burja, F. Tehovnik, J. Medved, M. Godec, M. Knap, Chromite spinel formation in steelmaking slags, Mater. Tehnol., 48 (2014) 5, 753-756

${ }^{9}$ G. Albertsson, L. Teng, B. Bjorkman, S. Seetharaman, F. Engstrom, Effect of Low Oxygen Partition in CaO-MgO-SiO2-Cr2O3-A12O3 Synthetic Slag at Elevates Temperatures, Steel Research International, 84 (2013) 7, 670-679, doi:10.1002/srin.201200214 
${ }^{10}$ A. Grochowalski, C. Lassen, M. Holtzer, M. Sadowski, T. Hudyma, Determination of PCDDs, PCDFs, PCBs and HCB Emissions from the Metallurgical Sector in Poland, Env Sci Pollut Res., 14 (2007) 5, 326-332, doi:10.1065/espr2006.05.303

${ }^{11}$ J. A. Roether, D. J. Daniel, D. Amutha Rani, D. E. Deegan, C. R. Cheeseman, A. R. Boccaccini, Properties of sintered glass-ceramics prepared from plasma vitrified air pollution control residues, Journal of Hazardous Materials, 173 (2010) 1/3, 563-569, doi:10.1016/ j.jhazmat.2009.08.123

${ }^{12}$ G. Montes-Hernandez, R. Perez-Lopez, F. Renard, J. M. Nieto, L. Charlet, Mineral sequestration of $\mathrm{CO} 2$ by aqueous carbonation of coal combustion fly-ash, Journal of Hazardous Materials, 161 (2009), 1347-1354, doi:10.1016/j.jhazmat.2008.04.104

${ }^{13}$ J. Jianguo, C. Maozhe, Z. Yan, X. Xin, Pb stabilization in fresh fly ash from municipal solid waste incinerator using accelerated carbonation technology, Journal of Hazardous Materials, 161 (2009), 1046-1051, doi:10.1016/j.jhazmat.2008.04.051

${ }^{14}$ H. Ecke, H. Sakanakura, T. Matsuto, N. Tanaka, A. Lagerkvist, State-of-the-art treatment processes for municipal solid waste incineration residues in Japan, Waste Management \& Research, 18 (2000) 1, 41-51, doi:10.1177/0734242X0001800106

${ }^{15}$ H. Ecke, N. Menad, A. Lagerkvist, Carbonation of municipal solid waste incineration fly ash and the impact on metal mobility, J. Environ. Eng. ASCE, 129 (2003) 5, 435-440, doi:10.1061/ (ASCE)0733-9372(2003)129:5(435)

${ }^{16}$ H. Ecke, N. Menad, A. Lagerkvist, Treatment-oriented characterization of metal-bearing dry scrubber residue from municipal solid waste incineration (MSWI), Journal of Material Cycles and Waste Management, 4 (2002) 2, 117-126

${ }^{17}$ H. Ecke, H. Sakanakura, T. Matsuto, N. Tanaka, A. Lagerkvist, Effect of electric arc vitrification of bottom ash on the mobility and fate of metals, Environmental Science \& Technology, 35 (2001) 7, 1531-1536, doi:10.1021/es0001759

${ }^{18}$ T. T. Eighmy, B. S. Crannell, L. G. Butler, F. K. Cartledge, E. F. Emery, D. Oblas, J. E. Krzanowski, J. D. J. Eusden, E. L. Shaw, C. A. Francis, Heavy metal stabilization in municipal solid waste combustion dry scrubber residue using soluble phosphate, Environmental Science \& Technology, 31 (1997) 11, 3330-3338, doi:10.1021/ es970407c
${ }^{19}$ E. Rendek, G. Ducom, P. Germain, Carbon dioxide sequestration in municipal solid waste incinerator (MSWI) bottom ash, J. Hazard. Mater., 128 (2006) 1, 73-79, doi:10.1016/j.jhazmat.2005.07.033

${ }^{20}$ T. Van Gerven, E. Van Keer, S. Arickx, M. Jaspers, G. Wauters, C. Vandecasteele, Carbonation of MSWI-bottom ash to decrease heavy metal leaching, in view of recycling, Waste Management, 25 (2005) 3, 291-300, doi:10.1016/j.wasman.2004.07.008

${ }^{21}$ M. Fernandez Bertos, X. Li, S. J. R. Simons, C. D. Hills, P. J. Carey, Investigation of accelerated carbonation for the stabilisation of MSW incinerator ashes and the sequestration of $\mathrm{CO}_{2}$, Green Chem., 6 (2004) 8, 428-436, doi:10.1039/B401872A

${ }^{22}$ X. Li, M. Fernandez Bertos, C. D. Hills, P. J. Carey, S. Simon, Accelerated carbonation of municipal solid waste incineration fly ashes, Waste Management, 27 (2007), 1200-1206, doi:10.1016/j.wasman. 2006.06.011

${ }^{23}$ G. Cappai, S. Carab, A. Muntoni, M. Piredda, Application of accelerated carbonation on MSW combustion APC residues for metal immobilization and $\mathrm{CO}_{2}$ sequestration, Journal of Hazardous Materials, 207-208 (2012), 159-164, doi:10.1016/j.jhazmat.2011. 04.013

${ }^{24}$ T. Sicong, J. Jianguo, Z. Chang, Influence of flue gas $\mathrm{SO}_{2}$ on the toxicity of heavy metals in municipal solid waste incinerator fly ash after accelerated carbonation stabilization, Journal of Hazardous Materials, 192 (2011), 1609-1615, doi:10.1016/j.jhazmat.2011. 06.085

${ }^{25}$ L. Wang, Y. Jin, Y. Niea, Investigation of accelerated and natural carbonation of MSWI fly ash with a high content of Ca, Journal of Hazardous Materials, 174 (2010), 334-343, doi:10.1016/j.jhazmat. 2009.09.055

${ }^{26}$ P. Gunning, C. Hills, A. Antemir, P. Carey, Novel approaches to the valorisation of ashes using aggregation by carbonation, Proc. of the 2nd International Slag Valorisation Symposium, Leuven, 2011, 103-116

${ }^{27}$ H. Katsuura, T. Inoue, M. Hiraoka, S. Sakai, Full-scale plant study on fly ash treatment by the acid extraction process, Waste Management, 16 (1996) 5/6, 491-499, doi:10.1016/S0956-053X(96)00091-8

${ }^{28}$ A. J. Chandler, T. T. Eighmy, J. Hartlén, O. Hjelmar, D. S. Kosson, S. E. Sawell, H. A. van der Sloot, J. Vehlow, Municipal Solid Waste Incinerator Residue, Studies in Environmental Science 67, Elsevier Science B. V., Netherlands 1997 